\title{
Hormonal residues in chicken carcasses
}

\author{
F. A. Khalafalla ${ }^{1 *}$, E. M. El-Neklway ${ }^{2}$, Hala A. M. Ibrahim ${ }^{2}$ \\ ${ }^{1}$ Department of Food Hygiene, Faculty of Veterinary Medicine, Beni-Suef University, Beni-Suef \\ Egypt and ${ }^{2}$ Department of Food Hygiene, Animal Health Research Institute, Dokki- Giza, Egypt
}

\begin{abstract}
Ninety chicks were experimentally, orally received different doses of estradiol-17 $\beta$ and diethylstilbestrol with ration. Samples were collected from tissues (wings, breast muscles, thigh muscles, skin and fat) and giblets (liver and gizzard) for detection of hormonal residues after 4 and 21 days from the last dose, which proved the presence of such residues in all samples. Effect of temperatures (boiling, roasting and freezing) on hormonal residues of positive samples was evaluated. It was proved that There is no significant variations in reduction of hormonal residues in each of breast and thigh muscles of chickens at $(p<0.05)$ after boiling, roasting and freezing at $20^{\circ} \mathrm{C}$ as well as a significant differences was detected in skin and fat samples at $(\mathrm{p}<0.05)$ after boiling and roasting. Public health importance of hormonal residues was discussed.
\end{abstract}

Hormonal residues in broilers carcasses caused significant public health hazards; because of the reports from toxicological experiments claiming to show that they may be associated with cancer.

The shortage of animal protein sources is considered the main reason for raising the production rates of animal protein with low cost and minimum delay. One of such trials is the use of growth promoters for increasing meat production.

Growth promoters are substances, which are added to feed components to improve the daily body gain. Therefore, many illegal methods were applied to increase animal production rates .The illegal trials may include the use of some chemicals or hormonal substances as growth promoters (Galli et al., 1989).

Anabolic agents are substances with physiological functions similar to those of human sex steroids, which increase nitrogen retention and protein deposition in farm animals (Heitzman, 1979; Hoffmann and Evers, 1986).

Administration of estrogenic substances to finishing cattle, sheep or poultry results in heavier carcasses containing more protein and moisture and less fat (Abu Akkada and ElShazly, 1975).

The use of anabolic agents is practically applied in many countries (Egypt is not

\footnotetext{
* Corresponding author. Tel.: +20 082 2322066; Fax: +200822327982

E-mail address: khalafalla@bsu.edu.eg

(Fathy A. khalafalla)
}

exception) for its benefits to increase the body gain despite of its great risk to the public health because of its properties to those of sex steroids, like androgens, progesterone and estrogens (ElGuindy, 1991).

The hazardous use of these agents received much attention, not only due to their anabolic effect on atherogenic lipids also but because of their deposition in the different edible parts of farm animals (Grandadam et al., 1975).

The most serious potential hazards arising from use of anabolic steroids is that of tissue residues of the substance and its metabolites. Children have been considered at great risk from exposure to hormonal residues because their normal physiological hormone levels are low as compared to adults.

The industry of poultry farms has been recently advanced in Egypt. Some of these farms add to the feed of birds some hormonal contraceptives in form of mixture of female sex hormones.

Therefore, this study was carried out to investigate the hormonal residues in broiler chicken experimentally administrated hormonal drugs. Moreover, the effect of temperatures was studied.

\section{Materials and methods}

Chicks. Ninety chicks (one day old) were kept under the same environment conditions and were given the same ration; vaccination and prophylactic program according to the system of (Lancater, 1963).They were reared at Animal Health Research Institute - Dokki - Giza. 
Table (1): Hormonal drugs used.

\begin{tabular}{ll}
\hline Name & Composition \\
\hline Microcept tablet & Each tablet contains $0.15 \mathrm{mg}$ Levonoregestrel and 0.03mg Ethinyl-estradiol produced by \\
& CID Company for Pharmaceutical Industries \\
DES & Commercial diethylstilbestrol powder obtained from Sigma Company \\
\hline
\end{tabular}

Experimental design. Chickens were divided into three groups at the 14th days. Two experiments were performed to detect and determine the tissue residues of oestradiol $17 \beta$ and DES and also to study the effects of temperatures on these residues. In addition one group was used as control.

Group (1) control group. This experiment consisted of 30 birds, fed on hormone free ration and received the same prophylactic program like the remaining other two groups, body weight, weight of giblets (liver and gizzard) and hormonal residues were recorded at 46 and 63 days.

Group (2). This experiment consisted of 30 birds, given contraceptive tablets Microcept tablet; at the 14th days each tablet contains $(0.15$ $\mathrm{mg}$ Levonoregestre and $0.03 \mathrm{mg}$ Ethinylestradiol). Each bird was given one tablet daily for 28 days with ration. Half the group was slaughtered at 4 days after the last dose. The body weight, weight of giblets (liver and gizzard) and hormonal residues in tissues (wings, breast muscle, thigh muscle, skin and fat) and giblets (liver and gizzard) were recorded at 46 days while the other half was kept alive and fed normal balanced ration till 21 days after the last dose. The hormonal residues in tissues (wings, breast muscle, thigh muscle, skin and fat) and giblets (liver and gizzard) were recorded.

Group (3). This experiment consisted of 30 birds. At 35 days the chicken were orally given diethylstilbestrol (DES) $5 \mathrm{mg}$ for 7 days. Half the group was slaughtered at 4 days after the last dose, The body weight, weight of giblets (liver and gizzard) and hormonal residues in tissues (wings, breast muscle, thigh muscle, skin and fat) and giblets (liver and gizzard) were recorded at 46 days. While the other half was kept alive and fed normal balanced ration till 21 days after the last dose. The hormonal residues in tissues (wings, breast muscle, thigh muscle, skin and fat) and giblets (liver and gizzard) were recorded.

\section{Technique for examination.}

1-Preparation of samples: Each chicken broiler carcass was divided into two equal parts one of them was used for determination of hormonal residues and the other for the effect of temperatures treatments.2-Extraction of hormones: Methods recommended by (Umberger et al., 1963; Rapp and Mayer, 1985) were used. 3-Determination: Methods recommended by (Umberger et al., 1963; De-Ruig et al., 1985; Rapp and Mayer, 1985) was applied.

Effect of temperatures on hormonal residues. Each half of broiler chicken carcass previously mentioned in experimentally administrated chicken for hormones was separately deboned for each of breast and thigh muscles. The muscles of each of breast and thigh were divided into three equal parts for the following examination.

Boiling. Samples included tissues (breast and thigh muscle as well as skin and fat), from each hormonal treatment after 4 days from last dose are subjected to boiling in Pyrex van, then a suitable amount of water was added. The samples were subjected to boiling for at least 30 minutes using electric heater, then hormonal residues were detected.

Roasting. Samples included tissues (breast and thigh muscle as well as skin and fat), from each hormonal treatment were rolled in aluminum foil and then heated in a hot air oven at $150^{\circ} \mathrm{C}$ for 30 minutes, the proper roasting was judged by naked eye, then re-examined for hormonal residues.

Freezing. Samples included tissues (breast muscle, thigh muscle and skin and fat), from the highest concentration are frozen at $-20^{\circ} \mathrm{C}$ for 3 months, and then re-examined for hormonal residues. Extraction and determination was applied as mentioned before.

\section{Results and Discussion}

Effect of hormones on body and giblets weight of chickens. From the obtained results illustrated in Table (2), it was showed the effect of orally administrated hormones on body and giblets weight (grams) of chickens after orally administration of Microcept $(0.03 \mathrm{mg}$ estradiol) for 28 days starting from 14 days ago and diethylstilbestrol (5mg DES) for 7days starting from 35 days ago. The mean body weight and 
weight of giblets after 4 days from the last dose (at 46 days) in either of untreated control chickens, orally administration either of Microcept and DES were 1730, 2287 and 2857 grams body weight; respectively (Table 1 ). The weight of livers was 29,37 and 44 grams; respectively as well as $36,42.5$ and 47 grams for gizzards; respectively.

Comparing with the increase in body weight between the untreated control chickens and orally administration of both Microcept and DES, the body weight were increased, each constituting $32 \%$ and $65 \%$; respectively, while in livers they were $28.5 \%$ and $53.5 \%$; respectively and finally in gizzard they were 18 $\%$ and $30 \%$; respectively.

There are significant differences between the increase in body weight and weight of giblets (liver and gizzard) between control and treated chicken with oral administration of either of microcept $(0.03 \mathrm{mg} / \mathrm{day})$ for 28 days and diethylstilbestrol $(5 \mathrm{mg} /$ day) for 7 days after 4 days from last dose at $p<0.05$ (Table 5).

A significant variation in weight of each of body and giblets (liver and gizzard) was detected between orally treated chicken by either of microcept and diethylstilbestrol at $\mathrm{p}<0.05$ (Table 5).

Nearly similar results were obtained by (Kraiter et al., 1961; El-Neklawy, 1989). In this respect, El-Saify, (1993) who reported that hormone treated birds hormonally treated with ethinyloestradiol or progesterone for 10 days, had highly significant increases in body weight.

This increase in body weight was due to estrogens mainly act through increase the growth hormone and insulin which is subsequently increase protein synthesis by increasing the amino acid uptake, favoring positive nitrogen balance, potentiate calcium and phosphorus retention and normalizing electrolyte balance. Also they improve the health of intestinal mucosa.

\section{Hormonal residues in tissues of treated chicken.}

Orally administration of $0.03 \mathrm{mg}$ estradiol. From the present data reported in (Table 3) it could be concluded that the mean values of estradiol residues in tissues of chickens treated by oral administration with Microcept $(0.03 \mathrm{mg}$ estradiol) for 28 days, in tissues (wings, breast muscle, thigh muscle and skinand fat) at 4 days after the last dose were $3.64 \pm 0.11,3.25 \pm 0.14$, $3.55 \pm 0.12$ and $8.49 \pm 0.11 \mathrm{ppb}$; respectively. While after 21 days from the last dose, it was
$0.099 \pm 0.01,0.085 \pm 0.01,0.087 \pm 0.02$ and $0.908 \pm 0.08 \mathrm{ppb}$; respectively.

The mean values of estradiol in liver and gizzard at 4 days after the last dose were $6.23 \pm$ 0.11 and $4.59 \pm 0.13 \mathrm{ppb}$; respectively. After 21 days from the last dose, it was $0.61 \pm 0.07$ and $0.45 \pm 0.08 \mathrm{ppb}$; respectively (Table4).

Comparatively, the estradiol residue levels in tissues of control were $0.02,0.02,0.02$ and 0.03 ppb for wings, breast muscle, thigh muscle as well as skin and fat; respectively. In giblets (liver and gizzard), the level were 0.03 and $0.02 \mathrm{ppb}$; respectively.

The obtained results of the hormonal residues in fat were higher than other samples; this may be attributed to that fat is the main reservoir of the hormonal residues. This substitutes the hypothesis reported by (Akiba et al., 1983) who stated that fat deposition increases due to the uses of hormones as growth promoters. Similar results were obtained by (FAO/WHO, 1987; Roushdy et al., 1992). Lower levels were reported by (El-Neklawy 1989; El-Guindy 1991). High levels were reported by (El- Shorbagy, 1997; Abu-Taleb 2003).

These differences may be attributed to the method of detection, the rout of hormone administration and the method where the sample were collected, and the chicken breed.

The obtained results after 21 days were similar to that obtained by (El-Neklawy, 1989; ElShorbagy, 1997). On the other hand, RichouBac et al., (1978) stated that the residues disappeared at 8 days.

The low levels of estradiol residues in tissues may be attributed to it has less active derivatives which include oestrone, oestriol, 16-epioestriol and 16- hydroxyl-oestrone and their conjugates with sulphate and glucuronic acid. This held the view explained by (De Groot, 1989). It is worth mentioning that feeding chickens with oral contraceptive steroids lead to formation of high estrogen residues in livers of treated chickens in comparison to untreated ones it held the view reported by (Sadek et al., 1998). Endogenous estrogens when given orally are largely metabolized during their first passage through the liver as well as diethylstilbestrol is resistant to hepatic metabolizes and when administered orally showed high oestrogenic activity this inaccordance with the hypothesis of preston, (1975); Page, (1991).

Orally administration of DES. Table ( 5 ) 
Table (2): Effect of orally administrated hormones (Microcept and DES) on body weight and weight of giblets (grams) of chickens after 4 days from the last dose.

\begin{tabular}{|c|c|c|c|c|}
\hline & & $\begin{array}{c}\text { Control } \\
\text { (Free ration) }\end{array}$ & $\begin{array}{c}\text { Microcept } \\
\text { (0.03 mg/day) } \\
\text { For 28 days } \\
\end{array}$ & $\begin{array}{c}\text { DES } \\
\text { (5mg/day) } \\
\text { For 7days }\end{array}$ \\
\hline \multirow{2}{*}{ Body } & Mean weight & $1730^{\mathrm{a}}$ & $2287^{\mathrm{b}}$ & $2857^{\mathrm{c}}$ \\
\hline & $\%$ & & 32 & 65 \\
\hline \multirow{3}{*}{ Liver } & Mean weight & $29^{\mathrm{a}}$ & $37^{\mathrm{b}}$ & $44^{\mathrm{c}}$ \\
\hline & $\%$ & & $2^{\vee} .6$ & 51.7 \\
\hline & Mean weight & $3 \overline{6}^{\mathrm{a}}$ & $42.5^{\mathrm{b}}$ & $47^{\mathrm{c}}$ \\
\hline Gizzard & $\%$ & - & 18 & 30.5 \\
\hline
\end{tabular}

DES $=$ Diethylstilbestrol $a, b$ and c superscripts within each row indicate significant difference at $\mathrm{p}<0.05$.

Table (3): Estradiol-17 $\beta$ residues (ppb) in tissues of chickens after orally administration of Microcept (0.03mg) for 28 days.

\begin{tabular}{lccccc}
\hline \multirow{2}{*}{ Days } & Examined & \multicolumn{3}{c}{ Microsept (0.03mg) orally } & \multirow{2}{*}{ Control } \\
\cline { 3 - 5 } & tissues & MIN & MAX & Mean \pm SE & \\
& Wings & 2.83 & 4.29 & $3.64 \pm 0.11$ & 0.02 \\
& Breast muscle & 2.39 & 4.16 & $3.25 \pm 0.14$ & 0.02 \\
& Thigh muscle & 2.63 & 4.28 & $3.55 \pm 0.12$ & 0.02 \\
21 days after the last dose & Skin and Fat & 7.78 & 9.17 & $8.49 \pm 0.11$ & 0.03 \\
& Wings & 0.03 & 0.21 & $0.099 \pm 0.01$ & 0.02 \\
& Breast muscle & 0.03 & 0.2 & $0.085 \pm 0.01$ & 0.02 \\
& Thigh muscle & 0.04 & 0.27 & $0.087 \pm 0.02$ & 0.02 \\
\hline $\mathrm{ppb}=\mu \mathrm{g} / \mathrm{kg}$ & Skin and Fat & 0.49 & 1.4 & $0.908 \pm 0.08$ & 0.03 \\
& MIN = Minimum & MAX=Maximum & SE = Standard error & &
\end{tabular}

Table (4): Estradiol-17 $\beta$ residues ( $\mathrm{ppb})$ in giblets of chickens after orally administration of Microcept $(0.03 \mathrm{mg})$ for 28 days.

\begin{tabular}{|c|c|c|c|c|c|}
\hline \multirow{2}{*}{ Days } & \multirow{2}{*}{ Examined tissues } & \multicolumn{3}{|c|}{ Microcept $(0.03 \mathrm{mg})$ orally } & \multirow{2}{*}{ Control } \\
\hline & & MIN & MAX & Mean \pm SE & \\
\hline \multirow[t]{2}{*}{4 days after the last dose } & Liver & 5.68 & 6.83 & $6.23 \pm 0.11$ & 0.03 \\
\hline & Gizzard & 3.71 & 5.37 & $4.59 \pm 0.13$ & 0.02 \\
\hline \multirow[t]{2}{*}{21 days after the last dose } & Liver & 0.19 & 0.99 & $0.61 \pm 0.07$ & 0.03 \\
\hline & Gizzard & 0.02 & 0.99 & $0.45 \pm 0.08$ & 0.02 \\
\hline
\end{tabular}

$\mathrm{ppb}=\mu \mathrm{g} / \mathrm{kg}$

MIN = Minimum

MAX=Maximum

$\mathrm{SE}=$ Standard error

Table (5): DES residues (ppb) in tissue of chickens after orally administration of DES (5mg) for 7 days.

\begin{tabular}{|c|c|c|c|c|c|}
\hline \multirow{2}{*}{ Days } & \multirow{2}{*}{ Examined tissues } & \multicolumn{3}{|c|}{ DES (5mg) orally } & \multirow{2}{*}{ Contro } \\
\hline & & MIN & MAX & Mean \pm SE & \\
\hline \multirow[t]{4}{*}{4 days after the last dose } & Wings & 8.33 & 9.93 & $9.36 \pm 0.13$ & ND \\
\hline & Breast muscle & 8.42 & 9.62 & $8.95 \pm 0.11$ & ND \\
\hline & Thigh muscle & 8.12 & 9.42 & $8.85 \pm 0.11$ & ND \\
\hline & Skin and Fat & 18.34 & 20.56 & $19.55 \pm 0.17$ & ND \\
\hline \multirow[t]{4}{*}{21 days after the last dose } & Wings & 0.03 & 0.8 & $0.41 \pm 0.08$ & ND \\
\hline & Breast muscle & 0.03 & 0.85 & $0.43 \pm 0.08$ & ND \\
\hline & Thigh muscle & 0.06 & 0.94 & $0.35 \pm 0.06$ & ND \\
\hline & Skin and Fat & 0.23 & 2.09 & $1.05 \pm 0.17$ & ND \\
\hline $\mathrm{ppb}=\mu \mathrm{g} / \mathrm{kg}$. & nimum & num & & & \\
\hline
\end{tabular}

Table (6): DES residues (ppb) in giblets of chickens after orally administration of DES (5mg) for 7days.

\begin{tabular}{llcccc}
\hline \multirow{2}{*}{ Days } & \multirow{2}{*}{ Examined tissues } & \multicolumn{4}{c}{ DES (5mg) orally } \\
\cline { 3 - 5 } Control \\
\hline 4 days after the last dose & Liver & 16.34 & 18.53 & $17.65 \pm 0.17$ & ND \\
& Gizzard & 13.71 & 15.62 & $14.65 \pm 0.15$ & ND \\
21 days after the last dose & Liver & 0.22 & 1.8 & $0.82 \pm 0.1$ & ND \\
& Gizzard & 0.03 & 1.37 & $0.72 \pm 0.11$ & ND \\
\hline
\end{tabular}

$\begin{array}{lll}\mathrm{ppb}=\mu \mathrm{g} / \mathrm{kg} & \text { Min. }=\text { Minimum } & \text { Max. }=\text { Maximum } \\ \mathrm{SE}=\text { Standard error } & \mathrm{ND}=\text { Not detected } & \mathrm{DES}=\text { Diethyl stilbestrol }\end{array}$


showed the diethylstilbestrol (DES) residues in tissue of chickens treated by oral administration of diethylstilbestrol (DES) as $5 \mathrm{mg}$ for 7 days; each constituting mean values of $9.36 \pm 0.13$, $8.95 \pm 0.11,8.85 \pm 0.11$ and $19.55 \pm 0.17 \mathrm{ppb}$ for each of tissues (wings, breast muscle, thigh muscle as well as skin and fat) at 4 days after the last dose; respectively.

Concerning diethylstilbestrol (DES) residues in chickens after 21 days from the last dose ; the mean values of diethylstilbestrol (DES) in tissues (wings, breast muscle, thigh muscle and skin and fat) were $0.41 \pm 0.08,0.43 \pm 0.08$, $0.35 \pm 0.06$ and $1.05 \pm 0.17 \mathrm{ppb}$; respectively.

The mean values of DES in giblets (liver and gizzard) at 4 days after the last dose were 17.65 \pm 0.17 and $14.65 \pm 0.15 \mathrm{ppb}$; respectively, while after 21 days from the last dose, were $0.82 \pm 0.1$ and $0.72 \pm 0.11 \mathrm{ppb}$ in giblets (liver and gizzard); respectively (Table 6).

All chickens used for detection of DES residues after oral administration were accompanied with control group, which proved to be free from any residues of hormone.

The risk of residues has to be evaluated by considering the differences existing between natural steroid hormones and synthetic agents as diethylstilbestrol (DES). All these compounds are individual chemical entities which, in addition to their hormonal activity may exhibit toxic effect. In this respect, Taylor, (1981) stated that the oxidation processes of estroid hormones may lead to reactive intermediates of electrophilic nature which can form covalent bonds and which could be responsible for the hepatic and renal toxicity and carcinogenesis.

On the other hand, Metzler, (1981) stated that DES has been shown to be a powerful genotoxic compound, able to act synergistically with other chemical carcinogens and give teratogenic and carcinogenic effects.

Generally from the outline view of Table (5, 6) it was distinctly cleared that skin, fat, liver and gizzard represented the highest residual levels for hormone residues and the lowest residual level was in muscle. Similar findings were mentioned by (Umberger et al., 1963; Herriman and Harwood, 1982). The decrease of DES residual level in chicken tissues and giblets may be attributed to that after 8 to 12 days orally administration of DES. The DES had been removed from the chicken tissues, however, the increase of faecal DES concentration due to the presence of metabolic intermediates of DES such as paraquinone (this being the precursor for the biosynthesis of dienestrol), of other DES metabolites such as dienestrol an whydroxydienestrol which give cross reactions with DES, or of free DES, produced as a result of bacterial action on DES- glucuronide in the intestine. This substitutes the hypothesis mentioned by (Fischer and Millburn, 1970; Preston 1975; Rico et al., 1981; Page 1991; Ersoy et al., 1993).

The elimination of DES from the body occurs primarily by way of faeces where residues are detected at the highest level for longest period) (Karg and Vogt, 1981; Ersoy et al., 1993). In this respect, Cubadda et al., (1964) registered that the oral administration of DES in chickens did not leave any significant residues in the meat at the end of the treatment. Hormonal activity was still present in chicken meat three months after the DES implant in the animal's necks. The synthetic non steroid hormones (diethylstilbestrol) are effective for long period in liver as compared to muscle due to the entrohepatic circulation during its metabolism. However, it is relatively resistant to biotransformation being also metabolized to highly reactive electrophilic intermediates capable of binding covalently to nucleic acids and protein. This agrees with that stated by (Hoffman et al., 1975; Page, 1991).

\section{Effect of temperatures on hormonal residues.}

Effect of boiling. From Table (7); it is showed that the mean values of estradiol $-17 \beta$ in tissues (breast muscle, thigh muscle as well as skinandfat) in zero time were $3.25 \pm 0.13,3.55 \pm$ 0.12 and $8.49 \pm 0.11 \mathrm{ppb}$ respectively, but after boiling, they were $3.15 \pm 0.14,3.4 \pm 0.12$ and $4.97 \pm 0.12 \mathrm{ppb}$; respectively as well as the mean values of estradiol $-17 \beta$ in soup were $0.08 \pm$ $0.01,0.09 \pm 0.004$ and $3.524 \pm 0.10 \mathrm{ppb}$; respectively.

It was revealed that the effect of boiling on estradiol $-17 \beta$ residues for 30 minutes was reduced in skin and fat, constituting reduction rate of $41.49 \%$ was average. This reduction in hormonal residues may be attributed to melting of fat during boiling in soup with their hormonal content. This agreed with the findings obtained by Ali, (2006). But in other tissues and giblet the reduction was not significant.

In this respect, Sadek et al., (1998) stated that the best method for cooking is boiling without skin, which contains fat. The mean values of DES in tissues (breast muscle, thigh muscle as well as skin and fat) in zero time were $8.95 \pm 0.11,8.85 \pm 0.11$ and $19.55 \pm 0.17 \mathrm{ppb}$; 
respectively, but after boiling,they were $8.7 \pm$ $0.11,8.55 \pm 0.11$ and $11.08 \pm 0.12 \mathrm{ppb}$; respectively and the mean values of DES in soup were $0.23 \pm 0.005,0.28 \pm 0.01$ and $8.44 \pm 0.07$ ppb; respectively (Table 8 ). The results were inagreement with findings of (Wozniak et al., 1999; Sultan, 2002).Therefore, from the present data, it could be concluded that boiling for 30 minutes of chickens treated with DES did not affect hormone content in case of Skin and fat it was reduced. The average reduction rate was $43.31 \%$.

Effect of roasting. The effect of roasting on the hormone residues in the tissues of treated chickens after oral administration of Microcept ( $0.03 \mathrm{mg}$ estradiol) for 28 days was shown in Table (7). The mean values of estradiol in tissues (breast muscle, thigh muscle as well as skin and fat ) in zero time were $3.25 \pm 0.14,3.55 \pm 0.13$ and $8.49 \pm 0.11 \mathrm{ppb}$; respectively but after roasting, each constituted $3.21 \pm 0.14,3.5 \pm 0.12$ and $7.27 \pm 0.15 \mathrm{ppb}$; respectively. The results were in accordance with (El-Neklawy, 1989; ElShorbagy, 1997; Sultan, 2002; Abu-Taleb, 2006).

Therefore, from the present data, it could be concluded that roasting reduces estradiol residues in skin and fat. The mean reduction rate was $14.47 \%$ but in other tissues this reduction was in significant.

Table (8) showed that the effect of roasting on the hormone residues in the tissues of treated chickens by oral administration of diethylstilbestrol (DES) $5 \mathrm{mg}$ for 7 days. The mean values of DES in tissues (breast muscle, thigh muscle as well as skinand fat) in zero time were $8.95 \pm 0.11,8.85 \pm 0.11$ and $19.55 \pm 0.17$ ppb; respectively, but after roasting, they were $8.83 \pm 0.11,8.73 \pm 0.11$ and $16.61 \pm 0.18 \mathrm{ppb}$; respectively. The results agreed with (Wozniak et al., 1999; Sultan, 2002).

Therefore, from the present data, it could be concluded that the roasting of chickens treated with DES didn't affect hormone residue except in Skin and fat the level was reduced and the average reduction rate was $15 \%$.

Effect of freezing. The hormone residues in the tissues (breast muscle, thigh muscle as well as skin and fat) of treated chickens by oral administration of Microcept $(0.03 \mathrm{mg}$ estradiol) for 28 days were $3.25 \pm 0.14,3.55 \pm 0.12$ and $8.49 \pm 0.11 \mathrm{ppb}$ in zero time; respectively but after freezing, they were $3.11 \pm 0.12,3.39 \pm$ 0.12 and $8.13 \pm 0.11 \mathrm{ppb}$; respectively, (Table7).
The effect of freezing at $-20^{\circ} \mathrm{C}$ for three months had undestructive effect on estradiol residues in tissues; this can be attributed to the fact that the hormonal residues are of great resistance against the application of low temperatures. Such findings were completely going with those recorded by (El- Neklawy, 1989; Roushdy et al., 1992; El-Bayomy, 1993; El-Shorbagy, 1997; Sultan, 2002; Abu-Taleb, 2003).

Dealing with the effect of freezing on the hormone residues in the tissues of treated chickens by oral administration of DES $5 \mathrm{mg}$ for 7 days (Table 8), the mean values of DES in tissues (breast muscle, thigh muscle as well as skinand fat) in zero time were $8.95 \pm 0.11,8.85$ \pm 0.11 and $19.55 \pm 0.17 \mathrm{ppb}$; respectively, and after freezing, they were $8.56 \pm 0.11,8.47 \pm 0.11$ and $18.72 \pm 0.17 \mathrm{ppb}$; respectively.

It is worthy to mention that freezing at $-20^{\circ} \mathrm{C}$ can not be relied upon as method of rendering chicken meat containing hormone residues in quantities more than permissible limit.

It was noticed that there was no effect of boiling for 30 minutes, roasting and freezing at $20^{\circ} \mathrm{C}$ for destruction of the estradiol residues. This can be attributed to the fact that the hormonal residues are of great resistance against the application of high or low temperature. These results were in agreement with the findings obtained by (El- Neklawy 1989; Roushdy et al., 1992; El-Bayomy, 1993; EL-shorbagy, 1997; Sultan, 2002; Abu-Taleb, 2006).

There is insignificant variations in reduction of estradiol residues in each of breast and thigh muscles of chicken orally administrated microcept $(0.03 \mathrm{mg}$ estradiol $)$ for 28 days at $(\mathrm{p}<$ 0.05 ) after boiling, roasting, and freezing at $20^{\circ} \mathrm{C}$ as well as a significant differences were only detected in skin and fat samples at $(\mathrm{p}<$ 0.05 ) after such treatments (Table 7). Significant differences were showed as decreasing in diethylstilbestrol residues in skin and fat samples of chickens orally administrated DES $(5 \mathrm{mg})$ for 7 days after boiling, roasting and freezing at $(\mathrm{p}<$ 0.05 ) while each of breast and thigh muscles had a weak significant after boiling and roasting as compared with freezing $(\mathrm{p}<0.05)$, (Table 8$)$.

From the achieved data, it could be concluded that, residues of natural steroidal hormones derived from treated birds are of negligible concern with respect to human health because residues in meat are of magnitude lower than those that occur naturally in birds. Synthetic non steroid hormones should be considered not only on the basis of their hormonal activity, but 
Table (7): Effect of temperatures on estradiol $-17 \beta$ residues in tissue (ppb) of chickens after orally administration of Microcept ( $0.03 \mathrm{mg}$ estradiol) for 28 days.

\begin{tabular}{|c|c|c|c|c|c|c|c|}
\hline & \multicolumn{2}{|c|}{ Breast muscle } & \multicolumn{2}{|c|}{ Thigh muscle } & \multicolumn{2}{|c|}{ Skin and fat } \\
\hline & & Mean \pm SE & Red. \% & Mean \pm SE & Red. \% & Mean \pm SE & Red. \% \\
\hline \multicolumn{2}{|c|}{ Before treatment } & $3.25^{\mathrm{a}} \pm 0.14$ & & $3.55^{\mathrm{a}} \pm 0.12$ & 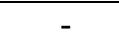 & $8.497^{a} \pm 0.11$ & - \\
\hline \multirow{2}{*}{ After boiling } & Tissue & $3.15^{\mathrm{a}} \pm 0.14$ & 3.1 & $3.43^{\mathrm{a}} \pm 0.12$ & 3.3 & $4.97^{\mathrm{b}} \pm 0.12$ & 41.5 \\
\hline & Soup & $0.08 \pm 0.01$ & - & $0.09 \pm 0.004$ & - & $3.524 \pm 0.10$ & - \\
\hline After roasting & & $3.21^{\mathrm{a}} \pm 0.14$ & 1.2 & $3.5^{\mathrm{a}} \pm 012$ & 1.5 & $7.27^{\mathrm{c}} \pm 0.15$ & 14.4 \\
\hline After freezing & & $3.11^{\mathrm{a}} \pm 0.12$ & 4.3 & $3.39^{\mathrm{a}} \pm 0.12$ & 4.4 & $8.13^{\mathrm{d}} \pm 0.11$ & 4.3 \\
\hline
\end{tabular}

$\mathrm{ppb}=\mathrm{ug} / \mathrm{kg}$

$\mathrm{SE}=$ Standard error

Red $\%=$ reduction $\%$

$a, b, c$ and $d$ superscripts within each column indicate significant difference at $(\mathrm{p}<0.05)$.

Table (8): Effect of temperatures on DES residues in tissue (ppb) of chickens after orally administration of DES $(5 \mathrm{mg})$ for 7 days orally.

\begin{tabular}{|c|c|c|c|c|c|c|c|}
\hline & \multicolumn{2}{|c|}{ Breast muscle } & \multicolumn{2}{|c|}{ Thigh muscle } & \multicolumn{2}{|c|}{ Skin and Fat } \\
\hline & & Mean \pm SR & Red. \% & Mean \pm SR & Red. \% & Mean \pm SR & Red. \% \\
\hline \multicolumn{2}{|c|}{ Before treatment } & $8.95^{\mathrm{a}} \pm 0.11$ & - & $8.85^{\mathrm{a}} \pm 0.11$ & - & $19.55^{\mathrm{a}} \pm 0.17$ & - \\
\hline \multirow[t]{2}{*}{ After boiling } & Tissue & $8.65^{\mathrm{a}, \mathrm{b}} \pm 0.11$ & 3.3 & $8.55^{\mathrm{a}, \mathrm{b}} \pm 0.11$ & 3.3 & $11.08^{b} \pm 0.12$ & 43.3 \\
\hline & Soup & $0.23 \pm 0.005$ & - & $0.28 \pm 0.01$ & - & $8.44 \pm 0.07$ & - \\
\hline & $8.83^{\mathrm{a}, \mathrm{b}} \pm 0.11$ & 1.3 & $8.73^{\mathrm{a}, \mathrm{b}} \pm 0.11$ & 1.3 & $16.61^{c} \pm 0.18$ & 15 \\
\hline \multicolumn{2}{|l|}{ After freezing } & $8.56^{\mathrm{b}} \pm 0.1$ & 4.4 & $8.47^{\mathrm{b}} \pm 0.11$ & 4.2 & $18.72^{\mathrm{d}} \pm 0.17$ & 4.2 \\
\hline \multicolumn{2}{|l|}{$\begin{array}{l}\mathrm{ppb}=\mu \mathrm{g} / \mathrm{kg} \\
\mathrm{Red}\end{array}$} & & $\begin{array}{l}=\text { Standa } \\
=\text { Dieth }\end{array}$ & $\begin{array}{l}\text { rror } \\
\text { tilbestrol }\end{array}$ & & & \\
\hline
\end{tabular}

also on the basis of other biological activities which may cause toxic effects. Misuse of illegal use of such substances led the consumers to be seriously concerned about this practice in poultry production. From the present data, it could be concluded that, there are significant differences between the increasing in body weight and weight of giblets (liver and gizzard) between control and treated chicken with orally administration of either of microcept $(0.03 \mathrm{mg} /$ day $)$ for 28 days and diethylstilbestrol $(5 \mathrm{mg} /$ day) for 7 days after 4 days from last dose at $\mathrm{p}<0.05$.

Orally administration of estradiol and diethylstilbestrol to broilers were indicated the presence of hormonal residues in different tissues with the highest concentration in skin and fat followed by liver, gizzard then muscles.

There are no significant variations in reduction of hormonal residues in each of breast and thigh muscles of chicken orally administrated of microcept and diethylstilbestrol at $(\mathrm{p}<0.05)$ after boiling, roasting and freezing at $-20^{\circ} \mathrm{C}$. As well as a significant differences was detected in skin and fat samples at $(p<0.05)$ after boiling and roasting as well as the freezing has no significant effect on hormonal residues.

The suggested recommendations included
Application of food management system (ISO 22000) as well as HACCP system for consumers' protection from hormonal residues

During cooking, removal of skin, fat, liver and kidneys is necessary for reduction of hormonal residues in cooked chicken, and can therefore be expected to reduce the consumption exposure risk to human health.

Advise the consumers not to use the soup after boiling the chickens.

\section{References}

Abu Akkada, A. R. and El- Shazly, K. (1975): Application of synthetic estrogens in sheep. FAO/WHO Symposium Rome.

Abu-Taleb, S. M. (2003): Determination of hormone residues in poultry meat products. Ph. D. Thesis, Faculty of Vet. Med. Zagazig Univ. Egypt.

Abu-Taleb, S. M. (2006): Some residues in some edible offal. Ph.D.Thesis, Fac. of Vet. Med. Cairo Univ., Egypt

Akiba, Y. K.; Kimura, M.; Hirama, S. I. and Matusmato, T. (1983): The influence of environmental temperature, thyroid status and a synthetic estrogen on the induction of fatty liver in chicks. Br. Poult. Sci., 24:71 -80.

Ali, F. H. (2006): Estradiol hormone residues in mutton and its variety meat. Vet. Med. J., Giza. 54: 205-213.

Cubadda, R. G.; Fabriani, A.; Fretoni, E. and Quattrucci, E. (1964): Ricerche dei residui ormonali nelle carni di pollo trattati con estrogenic. Quaderni Della Nutrizione, 24:187-201.

De Groot, J. L. (1989): Endocrinology. $2^{\text {nd }}$ ed., V. (1). London, Toronto. 
De Ruig, W. G.; Hooijerink, H. and Weseman, J. M. (1985): Detection of Anabolica in Meat by ThreeDimensional HPLC/HPTLC. Frese nius.Z, Anal. Chem. 320: 749- 752.

El-Bayomy, A.M. (1993): Residues in slaughtered food animals. Ph. D., Thesis, Fac. Vet. Med. Cairo Univ. Egypt. El-Guindy, N. M. (1991): Effect of estrogen addition in diet of chickens. M. Thesis, Fac. Sci. Alex.Univ. Egypt.

El-Neklawy, E. M. (1989): Determination of hormone residues in different kinds of meat. Ph.D., Thesis, Fac. Vet. Med., Cairo Univ. Egypt.

El Saify, A. (1993): Effect of ethinyloestradiol and progesterone on body weight and on serum glucose, GOT and GPT concentrations of male (balady) chicken for 10 and 20 days. Comp. Physiol., 10: 183-199.

El-Shorbagy, E. M. (1997): Hormonal residues in poultry meat and effect of some methods of preservation on it. $\mathrm{Ph}$. D. Thesis, Fac. Vet. Med., Zagazig Univ. Egypt.

Ersoy, E.; Agthe, O.; Ergun, H.; Sel, T. and Guldur, T. (1993): The determination of diethylstilbestrol (DES) in the faeces and tissues of chickens treated with DES and in faeces and tissue samples of calves, lambs and chickens collected from various areas of turkey. DeutscheTierarztliche - Wochenschrift 100: $450-453$.

FAO/ WHO (Food and agriculture organization / World Health Organization) (1987): Residues of some veterinary drugs in animal and foods. Thirty Second Meeting of the Joint FAO/WHO Expert Committee on Food Additives Rome, 15-23.

Fischer, L. J., and Millburn, P. (1970): Stilbestrol transport and glucoronide formation in everted sacs of rat intestine. Pharmacol. Exp. Ther., 175: 267 -275.

Galli C. L.; Marci A. and Qualtrucci (1989): Growth promoters, residues in food. Institute of Pharmacology and Pharmacogenosy Univ. of Milan, Italy.

Grandadam, J. A.; Schheid, J. P.; Jobard, A.; Dreux, H. and Boisson, J. M. (1975): Results obtained with trenbolon acetate in conjunction with estradiol $17 \mathrm{~B}$ in veal calves, Feed lot bulls, Lambs and pigs. J. Animal Sci., 41:968-977.

Heitzman, R. J. (1979): The efficacy and mechanism of action of anabolic agents as growth promotes in farm animals. J. Ster. Biochem., 11: 927- 935.

Herriman, I. D. and Harwood, D. J. (1982): Distribution of Hexoesterol residues in capanised chickens. Vet. Rec., 111: $435-436$.

Hoffmann, B. and Evers, P. (1986): Anabolic agents with sex hormone-like activities. Problems of residues. In: Rice, A.G. (ed.), Drug Residues in Animals, Academic Press, New York.

Karg, H. and Vogt, K. (1981): Residues of diethylstilbestrol (DES) in veal calves. Anabolic Agents in
Beef and Veal Production, CEC Workship, Brussels.

Kraiter, J.; Auskova, M. and Jelinek V. (1961): On the use of diethylstilbestrol in the fattening of cockerels. Sborn. Cstakad. Zone, Ved. Zivoc Vyr. 6(34): 721.

Lancaster, J. E. (1963): Newcastle disease control by vaccination. Common Wealth Bureau of Animal Health 2: $58-71$.

Metzler, M. (1981): Residues of anabolics in meat: risk for consumers, Health Aspects of Residues of Anabolics in Meat, Report on a WHO Work Group, Bilthoven, November 1981.

Page, S. W. (1991): Diethylstilbestrol clinical pharmacology and alternatives in small animal practice. Austra. Vet. J., 68: 226- 230.

Preston, R. L. (1975): Biological response to estrogen additive in meat producing calves and lambs. J.Anim. Sci., 44: 1414- 1420.

Rapp, V. M. and Meyer, H. H. D. (1985): Nachweismoglich keiten des trenbloneinsatzes in der Rindermast: Radioimmunologisch Bestimmung und Validierung der Ergebnisse mittels HPLC/RIA. Archiv. Fur Lebensmittel Hygiene 34: 29-52.

Richou-Bac, L.; Pochard M. and Boursier, B. (1978): Concentration of plasma and tissues of estradiol, oestrone and diethylstilbestrol in young cattle treated with anabolics. Receuil de Med. Vet., 154: 441-450.

Rico, A. G.; Burgot-Sacaze, V.; Braun, J. P. and Benard, P. (1981): Metabolism of endogenous anabolic agents in cattle. Anabolic agents in beef and veal production, CEC Workship, Brussels.

Roushdy, A. S.; El-Neklawy, E. M. and El-Bayomy, A. M. (1992): Estradiol residues in chicken tissues influence of freezing and cooking a hormone levels in chickens. Fleischwirtschaft, 72: $63-64$.

Sadek, I. A.; Ismail, H. M.; sullman, H. N. and Salim, M. (1998): Survey of hormonal levels in meat and poultry sold in Alexandria, Egypt. WHO Int. Pub. 4: 239 -243.

Sultan, H. M. (2002): Residual status of some growth promoters and chemotherapeutic in meat and offals of slaughtered cattle and sheep tissues. Ph .D. Thesis, Fac. Vet. Med., Cairo Univ. Egypt.

Taylor, W. (1981): Toxicology and carcinogenicity of anabolic agents in human subjects. Anabolic agents in beef and veal production, Workship, Brussels.

Umberger, E.; Banes, D.; kunze, F.; Sylvia, H. and Colson, H. (1963): Chemical determination of diethylstilboestrol residues in the tissue of treated chicken. J.A.O.A.C., 46:441-479.

Wozniak, B. C. (1999): Effect of freezing on anabolic hormone residues in bovine and poultry meat samples. Bull. Vet. Inst., (Pulaway) 42: 173 -176. 


\section{المتبقيات الهرمونية فى ذبائح الدواجن}

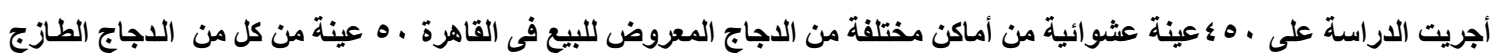

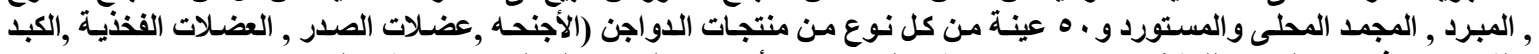

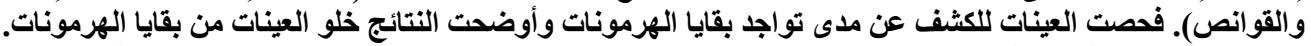

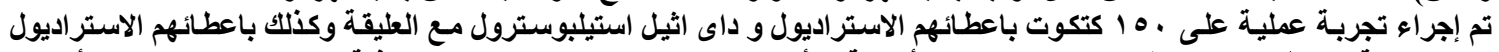

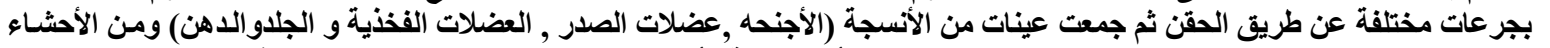

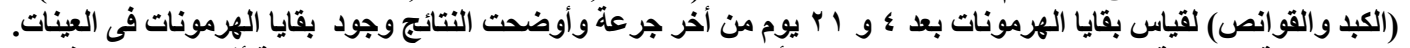

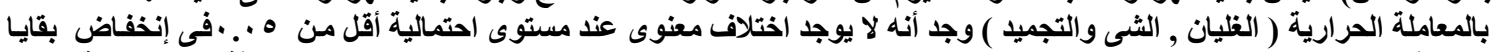

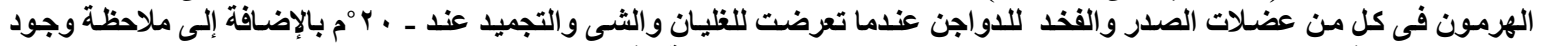

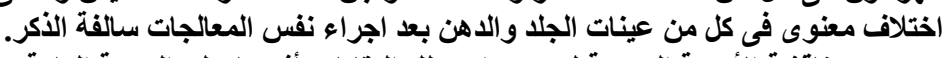

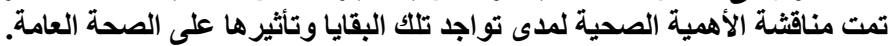

